Eğitim Teknolojisi kuram ve uygulama Kış 2017 Cilt 7 Sayı 1

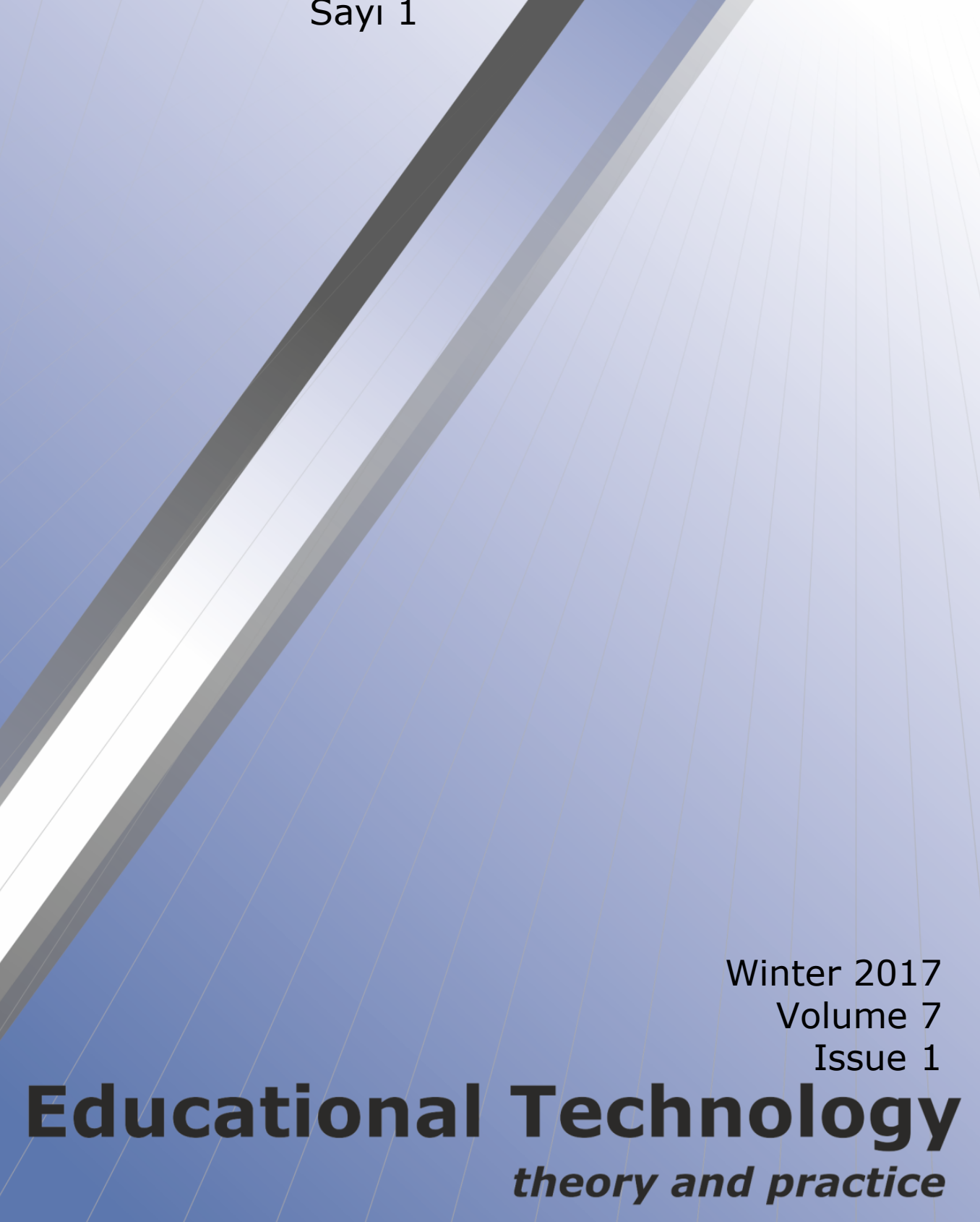


Cilt 7, Sayı 1, Kış 2017

Volume 7, Issue 1, Winter 2017

Genel Yayın Editörü / Editor-in-Chief: Dr. Halil ibrahim YALIN

Editör / Editor: Dr. Tolga GÜYER

Sorumlu Yazı İşleri Müdürü / Publisher Editor: Dr. Sami ŞAHiN

Redaksiyon / Redaction: Dr. Tolga GÜYER

Dizgi / Typographic: Dr. Tolga GÜYER

Sayfa Tasarımı / Page Design: Dr. Tolga GÜYER

Kapak Tasarımı / Cover Design: Dr. Bilal ATASOY

Illetişim / Contact Person: Dr. Aslıhan KOCAMAN KAROĞLU

Dizinlenmektedir / Indexed in: ULAKBiM Sosyal ve Beşeri Bilimler Veritabanı, Türk Eğitim İndeksi, ASOS Sosyal Bilimler İndeksi

\section{Editör Kurulu / Editorial Board*}

Dr. Abdullah Kuzu
Dr. Akif Ergin
Dr. Ana Paula Correıa
Dr. Aytekin İşman
Dr. Buket Akkoyunlu
Dr. Cem Çuhadar
Dr. Deniz Deryakulu
Dr. Deepak Subramony

Dr. Eralp H. Altun
Dr. Feza Orhan
Dr. H. Ferhan Odabaşı
Dr. Hafize Keser
Dr. Halil İbrahim Yalın
Dr. Hyo-Jeong So
Dr. İbrahim Gökdaş
Dr. Kyong Jee(Kj) Kim

Dr. Eralp H. Altun

Dr. Feza Orhan

Dr. Hafize Keser

Dr. Hyo-Jeong So

Dr. Kyong Jee(Kj) Kim
Dr. M. Oğuz Kutlu

Dr. M. Yaşar Özden

Dr. Mehmet Gürol

Dr. Michael Evans

Dr. Michael Thomas

Dr. Özcan Erkan Akgün

Dr. Özgen Korkmaz

Dr. S. Sadi Seferoğlu
Dr. Sandie Waters

Dr. Scott Warren

Dr. Servet Bayram

Dr. Şirin Karadeniz

Dr. Tolga Güyer

Dr. Trena Paulus

Dr. Yasemin Gülbahar Güven

Dr. Yavuz Akpınar

Dr. Yun-Jo An

\section{Hakem Kurulu / Reviewers*}

Dr. Adile Aşkım Kurt
Dr. Agah Tuğrul Korucu
Dr. Arif Altun
Dr. Aslıhan Kocaman Karoğlu
Dr. Ayça Çebi
Dr. Ayfer Alper
Dr. Aynur Kolburan Geçer
Dr. Ayşegül Bakar Çörez
Dr. Bahar Baran
Dr. Berrin Doğusoy
Dr. Bilal Atasoy
Dr. Deniz Atal Köysüren
Dr. Ebru Kılıç Çakmak
Dr. Ebru Solmaz
Dr. Emin İbili
Dr. Emine Şendurur
Dr. Erinç Karataş
Dr. Erhan Güneş
Dr. Erkan Çalışkan
Dr. Erkan Tekinarslan
Dr. Ertuğrul Usta
Dr. Fatma Keskinkılıç
Dr. Fezile Özdamlı

Dr. Filiz Kalelioğlu Dr. Gizem Karaoğlan

Dr. Gökçe Becit İşçitürk Dr. Gökhan Dağhan

Dr. Gülfidan Can

Dr. Halil Ersoy

Dr. Halil İbrahim Yalın

Dr. Halil Yurdugül

Dr. Hasan Çakır

Dr. Hasan Karal

Dr. Hatice Durak

Dr. Hüseyin Bicen

Dr. Hüseyin Özçınar

Dr. Işıl Kabakçı Yurdakul

Dr. İbrahim Gökdaş

Dr. İlknur Resioğlu

Dr. Kevser Hava

Dr. M. Fikret Gelibolu

Dr. Mehmet Akif Ocak

Dr. Mehmet Barış Horzum

Dr. Mehmet Kokoç

Dr. Melih Engin

Dr. Meltem Kurtoğlu
Dr. Mukaddes Erdem

Dr. Mustafa Serkan Günbatar

Dr. Mutlu Tahsin Üstündağ

Dr. Nadire Çavuş

Dr. Necmettin Teker

Dr. Necmi Eşgi

Dr. Nezih Önal

Dr. Nuray Gedik

Dr. Nurettin Şimşek

Dr. Onur Dönmez

Dr. Ömer Faruk İslim

Dr. Ömer Faruk Ursavaş

Dr. Ömür Akdemir

Dr. Özcan Erkan Akgün

Dr. Özden Şahin İzmirli

Dr. Özgen Korkmaz

Dr. Özlem Çakır

Dr. Ramazan Yılmaz

Dr. Recep Çakır

Dr. Sami Acar

Dr. Sami Şahin

Dr. Selay Arkün Kocadere

Dr. Selçuk Özdemir
Dr. Serap Yetik

Dr. Serdar Çiftçi

Dr. Serçin Karataş

Dr. Serpil Yalçınalp

Dr. Sibel Somyürek

Dr. Şafak Bayır

Dr. Şeyhmus Aydoğdu

Dr. Şirin Karadeniz

Dr. Tayfun Tanyeri

Dr. Tolga Güyer

Dr. Tolga Kabaca

Dr. Türkan Karakuş

Dr. Uğur Başarmak

Dr. Ümmühan Avcı Yücel

Dr. Ünal Çakıroğlu

Dr. Veysel Demirer

Dr. Yalın Kılıç Türel

Dr. Yasemin Demirarslan Çevik

Dr. Yasemin Gülbahar Güven

Dr. Yasemin Koçak Usluel

Dr. Yavuz Akbulut

Dr. Yusuf Ziya Olpak

Dr. Yüksel Göktaş

\section{Illetişim Bilgileri / Contact Information}

Internet Adresi / Web: http://dergipark.ulakbim.gov.tr/etku/

E-Posta / E-Mail: tguyer@gmail.com

Telefon / Phone: +90 (312) 2021738

Belgegeçer / Fax: +90 (312) 2028387

Adres / Adress: Gazi Üniversitesi, Gazi Eğitim Fakültesi, Bilgisayar ve Öğretim Teknolojileri Eğitimi Bölümü, 06500 Teknikokullar - Ankara / Türkiye 


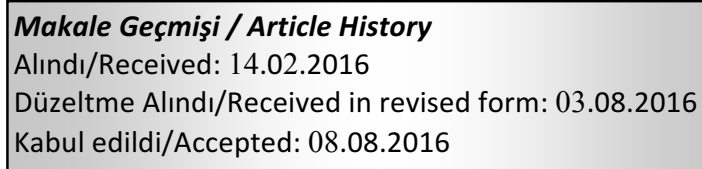

\title{
INTERNET USE FOR EDUCATIONAL PURPOSES: UNIVERSITY STUDENTS' ATTITUDES AND OPINIONS ABOUT COPYRIGHTS*
}

\author{
Murat AKÇAYIR ${ }^{1}$, Gökçe AKÇAYIR²,
}

\begin{abstract}
Internet has become available anytime and anywhere with the advent of mobile communications devices and 3G technology. Today's university students are using internet actively for educational purposes. In Internet, widely used by students, it is very easy to copy and paste every kind of content and this gives rise to the question of "Is enough attention paid to copyright?" and this causes some concerns in educational circles. Therefore, in the present study, the state of Internet use by university students for educational purposes, their current opinions about the issue of copyright, how they perceive of copyrights and their suggestions to prevent copyright violations were investigated. The present study conducted with the participation of 223 university students employed both qualitative and quantitative data collection instruments. The findings of the study revealed that university students are using Internet extensively for educational purposes; yet, they can easily overlook copyright issues. It was determined that the most common reason for students to violate copyrights is their not encountering any sanctions.

Keywords: Copyright; higher education; Internet use for educational purposes; educational material
\end{abstract}

\footnotetext{
* A part of this study was presented in the "IX. European Conference on Social and Behavioral Sciences", on 36 February, 2016 Paris/FRANCE.

${ }^{1}$ Arş. Gör. Dr., Kırıkkale Üniversitesi, murat_akcayir@hotmail.com

${ }^{2}$ Arş. Gör., Gazi Üniversitesi, gokceakcayir@gmail.com
} 


\title{
EĞiTiMSEL AMAÇLI INNTERNET KULLANIMI: ÜNIVERSITE ÖĞRENCILERININ TELIF HAKLARI HAKKINDA TUTUM VE GÖRÜŞLERI
}

\author{
Öz
}

Internet mobil cihazlar ve $3 G$ teknolojisi ile elimizin altında her an ulaşılabilir bir hâl almıştır. Günümüzde üniversite öğrencileri interneti eğitim amaçlı olarak aktif bir şekilde kullanmaktadır. Öğrencilerin yoğun olarak kullandıkları internette kolay bir şekilde kopyala yapıştır mekanizmasının olması akıllara "Telif haklarına dikkat ediliyor mu?" sorusunu getirmekte ve bu durum eğitim ortamlarını tedirgin etmektedir. Bu nedenle yapılan bu çalışmada üniversite öğrencilerinin eğitimde internet kullanım durumları, eğitimde telif hakları konusundaki mevcut fikirleri, telif haklarını nasıl algıladıkları ve özellikle telif hakları ihlalini önlemeye yönelik kendi önerileri belirlenmiştir. Toplamda 223 üniversite öğrencisinin katıldığı bu araştırmada hem nitel hem de nicel veri toplama araçları kullanılmıştır. Elde edilen bulgulara göre üniversite öğrencileri interneti eğitimsel amaçlı oldukça yoğun bir şekilde kullanmalarına karşın telif haklarını göz ardı ettikleri belirlenmiştir. Öğrencilerin telif haklarını ihlal etme nedenleri, mevcut durumları, telif haklarına yönelik tutumları ayrıntıı olarak tartışılmıştır. Ayrıca ortaya çıkan mevcut durum için literatüre dayalı olarak öneriler verilmiştir.

Anahtar Kelimeler: Telif hakları; yükseköğretim; eğitim amaçlı internet kullanımı; eğitsel materyal 


\section{Geniş Özet}

Günümüz teknoloji çağında bilgiler dijital ortamlara taşınmış ve kolay transfer edilir bir hâl almıştır (Mir, 2014). İnternetin yaygınlaşması 3G ve Wi-Fi teknolojisi ile her an ulaşılabilir olması ve hızının artmasında yanında tablet bilgisayar ve akıllı telefon gibi yeni teknolojik ürünlerin kullanım oranının artması da bilgilerin internet ortamından elde edilmesine ve paylaşılmasına olanak sağlamıştır. Özellikle üniversite öğrencileri için internet kaçınılmaz bir iletişim aracı olmakla beraber aynı zamanda bir eğitim aracıdır (Huang, 2010). Internette bilgi trafiğinin oldukça yoğun olması ve bilgilerin kolayca kopyalanıp yapıştırılabilir olması, telif haklarıyla ilgili endişelere neden olmaktadır. İnternet kullanıcıları bilerek ya da kazara telif hakları alınmış bir içeriği farklı kişilere izinsiz dağıtabilmektedir (Çelik ve Akçayır, 2012). Günümüzde üniversite öğrencileri interneti eğitim amaçlı olarak yoğun bir şekilde kullanmakta ve başkalarından aldıkları bir materyali izinsiz bir şekilde kullanabilmektedir.

Geçmiş yıllarda araştırmacılar, öğrencilerin telif hakları hususuna dikkat etmediği, telif hakları ihlalinde artışın olduğu ve eğitim için problem teşkil ettiğini belirtmişlerdir (Austin ve Brown, 1999). Günümüzde telif hakları konusu halen eğitim ortamlarında sorun olmaktadır (Beycioglu, 2009; Çelik ve Akçayır, 2012). Eğitimde telif hakları ihlali farklı şekillerde gerçekleşebilmektedir. Örneğin sahibinin izni olmadan bilginin kullanılması, çoğaltılması, başka ortamlarda yayılması, başkasının çalışmasına uyarlaması telif hakları ihlaline girmektedir.

Literatürde yer alan araştırmalara rağmen özellikle yükseköğretimde telif hakları ihlali günümüzde halen eğitimcileri tedirgin eden bir unsur olarak durmakta ve eğitim sürecinde bir engel teşkil etmektedir (Çelik ve Akçayır, 2012; Szabo ve Underwood, 2004). Bu nedenle yapılan bu çalışmada yükseköğretim öğrencilerinin eğitimde internet kullanım durumları, eğitimde telif hakları konusundaki mevcut fikirleri, telif haklarını nasıl algıladıkları ve özellikle bu sorunun çözümüne yönelik kendi önerileri belirlenmiştir.

Bu çalışmada nicel ve nitelin yaklaşımların birlikte kullanıldığı karma yöntem kullanılmıştır. Çalışmaya Kırıkkale Üniversitesinde öğrenim gören 223 üniversite öğrencisi katılmıştır. Katılımcılar arasından gönüllü olan 20 öğrenci ile görüşme yapılmıştır. Nicel veri toplama aracı olarak 21 maddeden oluşan Çelik ve Akçayır (2012) tarafından uyarlanan 5'li likert tipi (1 kesinlikle katılmıyorum - 5 kesinlikle katılıyorum) 3 faktörlü ölçek kullanılmıştır. 11 madde katılımcıların telif hakları hakkında var olan bilgilerini (BC), 4 madde telif hakları alınmış bir materyal kullanma niyetlerini (AICM) ve 6 madde eğitimde telif hakları algıları (PCE) ile ilgilidir. Yapılan bu çalışmada Cronbach Alpha güvenirlik katsayısı 0.78 çıkmıştır. Araştırmada nicel verileri daha iyi yorumlamak, desteklemek ve derinlemesine veri elde etmek için yarı yapılandırılmış görüşme yapılmıştır.

Çalışmada açık bir şekilde öğrencilerin aktif bir şekilde interneti eğitimsel amaçlı olarak kullanmalarına rağmen telif haklarına dikkat etmedikleri ve önemsemedikleri görülmektedir. Jenkins' in (2006) de belirttiği gibi öğrenciler kendilerine özgü bir etik norm oluşturmuş durumdadır. Öğrenciler telif haklarını hiç düşünmeden istedikleri materyali gerekiyor ise kullanabilmektedir. Benzer sonuç Huang (2010) tarafından yapılan çalışmada da elde edilmiştir. Üniversitelerin telif hakları ihlalini önlemede rol üstlenerek eğitici ve açık yol gösterici olması gerekmektedir (Austin ve Brown, 1999; Heffernan ve Wang, 2008; Szabo ve Underwood, 2004 ). Üniversiteler kendilerine özgü bir telif hakları politikası geliştirip 
uygulayabilir (Loggie vd, 2006). Geliştirilen okul politikası web sitesine, afiş olarak basılıp ortak kullanım alanları olan kütüphane ve bilgisayar laboratuvarı gibi yerlere asılabilir.

\section{Introduction}

In this technology era, information is stored in digital media and has become easy to transfer (Mir, 2014). Storage of information in Internet in digital forms has enabled people to have easy access to information, copy and paste it (Arnold, Schmucker, \& Wolthusen, 2002). Spread of Internet, it's becoming always available by means of $3 \mathrm{G}$ and Wi-Fi technologies and its increasing speed and increase in the utilization ratios of new technological products such as tablet pc and smart mobile phone have facilitated the retrieval and sharing of information through Internet. Nowadays people are using Internet actively for different purposes such as reading news, communicating, conducting transactions, entertainment and education (Karim, Zamzuri, \& Nor, 2009). Particularly for university students under 25 years old, Internet has become an indispensable educational and communication tool (Huang, 2010).

According to Mir (2014), information and security are interconnected disciplines. Intense traffic of information on Internet and its being easily copied and pasted have given rise to the question of "Is enough attention paid to copyright issues?" (Beycioglu, 2009; Tang, 2010). Internet users may on purpose or by mistake deliver content that is under the protection of copyright law to other people without permission (Çelik \& Akcayir, 2012). Today, university students are using Internet extensively for educational purposes and they are in danger of using materials taken from different sources without permission (Akbulut, Uysal, Odabasi, \& Kuzu, 2008).

While students are expected to be respectful to others' rights, Internet has created a new generation of students eager to make use of immediate and ready-to-use information (Renard, 1999). Internet allowed to display academically unethical behaviors such as, plagiarism, piracy and falsification (Ross, 2005; Szabo \& Underwood, 2004). In short, Internet's mechanism of easily downloading, copying and pasting information causes concern for academic milieu (Frohmann, 2008; Karim et al., 2009; Lau \& Yuen, 2014). However, Internet should be used to build up new information on already existing information rather than directly copying and pasting information (Mir, 2014).

\section{Copyright issues in educational Internet use}

In Internet, there are many instructional materials under the protection of copyright for students and teachers (Loggie et al., 2006). In the field of education, the danger of violating copyrights is not a new phenomenon. In the past, researchers stated that students did not pay attention to copyright issues, there was an increase in the violation of copyrights and this posed a threat to education (Austin \& Brown, 1999). Today, copyright issues still constitute a problem in educational environments (Beycioglu, 2009; Çelik \& Akcayir, 2012).

In education, copyright violation occurs in different ways. For instance, use of information without the consent of its owner, its reproduction and dissemination in other media and adaptation of it in another study are some forms of copyright violation. Software 
programs we set up in our computers, multi-media materials, e-books, course notes and web-based course content are some of intellectual properties that can be found in Internet. In addition to these, blogs where students upload their assignments and share them with each other are considered within the context of intellectual properties. In recent years, besides violation of copyrights, there have been attacks on web environment and all of these have resulted in a need for different security mechanisms (Mir, 2014).

As a result of the increase in demand for distance education, the need for course materials in Internet environment has also increased (Twigg, 2000). Educational institutions having commercial concerns started to show a tendency to use the already existing materials in Internet (Mabry \& O'Driscoll, 2003). This may lay the ground for violation of copyrights not only by students but also by educational institutions. There are also some cases in which educators may lay the ground for copyright violations. University professors usually develop materials and share them in Internet and while developing their materials, they may directly copy information from hard copy materials without permission and in this way they may exhibit an unethical behavior (Lan \& Dagley, 1999). In short, in the field of education, copyright issues can be considered under three headings; institution, educator and student.

\section{Purpose of the study}

Though there is a large amount of research dealing with copyright infringements, violation of copyrights particularly at higher education is still an issue bothering educators and adversely affecting the quality of education process (Çelik \& Akcayir, 2012; Szabo \& Underwood, 2004). Besides educators, educational institutions and publishers are experiencing some problems due to students' indifference to copyright issues (DeFosse, 2012). More frequent use of technology and Internet for educational purposes also results in an increase in copyright infringements (Karim et al., 2009; Whitley \& Starr, 2010). Though the existing research adequately deals with copyright infringements in relation to factors such as gender and socio-economic status, not much emphasis is put on the opinions, expectations and awareness of university students (Beycioglu, 2009; Lin, 2007; Mir, 2014). Lau and Yuen (2014) stress the need to concentrate on the issue from different perspectives, to determine the real causes of students' exhibiting unethical behaviors and to support the related research with qualitative data. Thus, students' awareness of copyright issues, their current viewpoints and their expectations should be considered in order to deal with the issue in a more detailed manner. In line with this purpose, the present study investigated the present state of university students' use of Internet, their opinions about copyright issues in education, how they perceive of copyrights and their suggestions for the solution to this problem. Thus, the research questions of the current study are structured as follows;

RQ1: What is the state of the university students' internet use for educational purposes?

RQ2: Which internet sites do the university students use for educational purposes?

RQ3: What are the university students' attitudes towards copyrights?

RQ4: What are the university students' opinions about copyright issues in education? 


\section{Method}

\section{Participants}

The participants of the study are undergraduate students from the Education Faculty of Kırıkkale University in Turkey. The method of sampling was convenience sampling. The questionnaires were distributed to 283 participants (grades one through four); yet, 223 students returned complete questionnaires. As a result, data of the study were collected from 151 female $(67.71 \%)$ and 72 male (32.29\%) students. The ages of the participants range from 18 to 23 . Moreover, semi-structured interviews were conducted with 20 voluntary students.

\section{Instruments and procedure}

In the present study, mixed method was employed by using both qualitative and quantitative data collection instruments. As stated by Kuzu (2009), while quantitative data are used to give an answer to question "What", qualitative data are used to give an answer to question "Why". It proved to be very difficult to find a scale specially prepared to investigate copyrights and ethics in the literature (Lau \& Yuen, 2014). Thus, researchers investigating these issues either preferred to develop their own scales or adapted the developed scales into their research (Çelik \& Akcayir, 2012; Karim et al., 2009; Lau \& Yuen, 2014; Underwood \& Szabo, 2003; Whitley \& Starr, 2010). In the present study, as a quantitative data collection instrument, 21-item scale adapted from Çelik and Akcayir (2012) was used. The scale is a three-factor scale in the form of five-point Likert-type ranging from 1 strongly disagree to 5 strongly agree. Eleven of the questionnaire items aim to elicit the participants' background about copyright law (BC), 4 items aim to elicit their attitudes towards and intentions in using copyrighted materials (AICM) and 6 items are related to perceptions of copyright issues in education (PCE). The Cronbach's Alpha reliability coefficient of the original scale was reported to be 0.81 (Çelik \& Akcayir, 2012).

In addition to these 21 items, some items to explore the gender of the participants, how frequent they use Internet for educational purposes and which sites they use were added to the questionnaire.

The participants were asked to complete a survey during a regular class session. Participation was voluntary. The researchers explained the purpose of the study to the participants. Those who were willing to participate read a consent form and filled out the survey.

Semi-structured interviews were conducted to better interpret and support the quantitative data and to obtain more detailed data. The interviews were conducted with students on the voluntary basis. Each interview lasted for about ten minutes. Within the context of the semi-structured interviews, the students were asked;

Whether they have some information about copyright issues and if yes, where have they learned this information,

Whether they care about copyrights; if not, why, 
Why copyrights are violated,

What their suggestions are for the prevention of copyright infringements.

\section{Data analysis}

First, the reliability analysis of the quantitative analysis data was conducted through SPSS. In the present study, Cronbach's Alpha reliability coefficient of the questionnaire was found to be 0.78 . Then, the quantitative data were analyzed by using descriptive statistic methods.

In the analysis of the qualitative data, content analysis method was employed. The raw data obtained from the student interviews were coded and in this way, codes and themes were determined (Elo \& Kyngäs, 2008). The data were classified under these categories and digitized and thus made meaningful for the reader.

\section{Results}

\section{RQ1: What Is The State of The University Students' Internet Use For Educational Purposes?}

The results of the analysis of the questionnaires show that the students do not restrict their education with the information taken from the school, but actively use Internet for educational purposes (see Table 1). None of the 223 students participating in the present study stated that they never use Internet. When the male and female students' internet use for educational purposes was examined, it was found that their use is very similar to each other. Many of the students (45.29\%) use Internet frequently. In short, Internet is a useful means of learning for students.

Table 1: The students' state of Internet use for educational purposes

\begin{tabular}{llll}
\hline Rate & $\begin{array}{l}\text { Gender } \\
\text { (Male=72, Female=151) }\end{array}$ & $f$ & $\%$ \\
\hline Never & Male & 0 & 0.00 \\
& Female & 0 & 0.00 \\
\hline A few times a semester & Male & 1 & 1.38 \\
& Female & 9 & 5.96 \\
\hline A few times a month & Male & 13 & 18.05 \\
& Female & 17 & 11.25 \\
\hline A few times a week & Male & 30 & 41.66 \\
& Female & 52 & 34.43 \\
\hline Frequently & Male & 28 & 38.88 \\
& Female & 73 & 48.34 \\
\hline
\end{tabular}




\section{RQ2: Which Internet Sites Do The University Students Use For Educational Purposes?}

Nearly all of the students (91.92\%) use Google for educational research (see Table 2). The students were found to conduct primarily key word search in Google. Another popular site visited by the students is Wikipedia (56.05\%). When Table 2 is examined, it is seen that the students also use social media sites for educational purposes. Popular sites such as YouTube, Facebook and Twitter are among the sites visited by the students. Moreover, the students visit forums and blogs for educational purposes. Small ratio of the participants $(4.48 \%)$ marked "others" option. Among the web sites mentioned by the students marking "others" option are there religious education sites and private tutoring sites.

Table 2: Sites used by the students for educational purposes

\begin{tabular}{llll}
\hline Web sites & Gender & $f$ & $\%$ \\
& (Male=72, Female=151) & & \\
\hline Google & Male & 65 & 90.27 \\
& Female & 140 & 92.71 \\
\hline Wikipedia & Male & 46 & 63.88 \\
& Female & 79 & 52.31 \\
\hline YouTube & Male & 37 & 51.38 \\
& Female & 87 & 57.61 \\
\hline Facebook & Male & 34 & 47,22 \\
& Female & 63 & 41.72 \\
\hline Forums & Male & 29 & 40.27 \\
& Female & 33 & 21.85 \\
\hline Google Scholar & Male & 15 & 20.83 \\
& Female & 36 & 23.84 \\
\hline Blogs & Male & 24 & 33.33 \\
& Female & 20 & 13.24 \\
\hline Twitter & Male & 12 & 16.66 \\
& Female & 15 & 9.93 \\
\hline Other & Male & 8 & 11.11 \\
& Female & 2 & 1.32 \\
\hline
\end{tabular}

\section{RQ3: What Are The University Students' Attitudes Towards Copyrights?}

One of the purposes of the present study is to explore the students' existing knowledge about copyrights regulations. The findings show that the existing knowledge of the students is at medium level (see Table 3). This indicates that there are many female (mean $=3.21, \mathrm{sd}=1.38$ ) and male students (mean $=3.25$, sd $=1.29$ ) who do not know much about copyright laws. The findings of the current research revealed that almost all of the students (95.51\%) stated that they use Internet at least once per month. High ratio of the students using Internet actively for educational purposes and medium level of BC scores indicate that the students do not much care about copyright issues. AICM scores of the female students (mean $=3.10, s d=1.28$ ) and male students (mean $=3.09$, $s d=1.21$ ) were found to be at medium level. That is, the participants seem to be undecided about whether copyright regulations are necessary for educational materials. Though there are some legal 
punishments for copyright infringements, the students' attitudes towards the illegal use of educational materials were found to be medium.

The students' PCE scores were found to be low (see Table 3). This finding shows that the students think that use of educational materials in educational environments is not a violation of copyrights. There is a perception among the students that a material shared in Internet environment without the required permission is not a violation of copyrights. There is a perception that a material available in Internet medium can be used freely.

Table 3: Scores taken by the students from the questionnaire

\begin{tabular}{|c|c|c|c|c|c|}
\hline Item & $\begin{array}{l}\text { Strongly } \\
\text { disagree }\end{array}$ & Disagree & $\begin{array}{l}\text { Neither } \\
\text { agree/ } \\
\text { disagree }\end{array}$ & Agree & $\begin{array}{l}\text { Strongly } \\
\text { Agree }\end{array}$ \\
\hline & $\mathrm{n}(\%)$ & $\mathrm{n}(\%)$ & n (\%) & $\mathrm{n}(\%)$ & $\mathrm{n}(\%)$ \\
\hline \multicolumn{6}{|l|}{ Background about copyright law (BC) } \\
\hline $\begin{array}{l}\text { 1. I think I know what the term } \\
\text { copyright means and refers to. }\end{array}$ & $\begin{array}{l}36 \\
(16.14)\end{array}$ & $58(26.00)$ & $\begin{array}{l}93 \\
(41.70)\end{array}$ & $\begin{array}{l}24 \\
(10.76)\end{array}$ & $\begin{array}{l}12 \\
(5.38)\end{array}$ \\
\hline $\begin{array}{l}\text { 2. I have had adequate education on } \\
\text { copyright regulations. }\end{array}$ & $\begin{array}{l}75 \\
(33.63) \\
\end{array}$ & $76(34.08)$ & $\begin{array}{ll}50 \\
(22.42)\end{array}$ & $\begin{array}{l}17 \\
(7.62)\end{array}$ & $5(2.24)$ \\
\hline $\begin{array}{l}\text { 3. I know about the organizations such as } \\
\text { Creative Commons }(\mathrm{CC}) \text { aiming to provide } \\
\text { flexibility on the fair use of materials. }\end{array}$ & $\begin{array}{l}73 \\
(32.73)\end{array}$ & $80(35.87)$ & $\begin{array}{l}52 \\
(23.32)\end{array}$ & $\begin{array}{l}13 \\
(5.83)\end{array}$ & $5(2.24)$ \\
\hline $\begin{array}{l}\text { 4. My knowledge on copyright originates } \\
\text { from the talks with friends. }\end{array}$ & $\begin{array}{l}51 \\
(22.87)\end{array}$ & $63(28.25)$ & $\begin{array}{l}61 \\
(27.35)\end{array}$ & $\begin{array}{l}36 \\
(16.14)\end{array}$ & $\begin{array}{l}12 \\
(5.38)\end{array}$ \\
\hline $\begin{array}{l}\text { 5. My knowledge on copyright originates } \\
\text { from Internet and Television. }\end{array}$ & $20(8.97)$ & $45(20.18)$ & $\begin{array}{l}90 \\
(40.36)\end{array}$ & $\begin{array}{l}52 \\
(23.32)\end{array}$ & $\begin{array}{l}16 \\
(7.17)\end{array}$ \\
\hline $\begin{array}{l}\text { 6. I am in need of education on the ethical } \\
\text { use of digitalized educational materials on } \\
\text { Internet. }\end{array}$ & $11(4.93)$ & $35(15.70)$ & $\begin{array}{l}65 \\
(29.15)\end{array}$ & $\begin{array}{l}53 \\
(23.77)\end{array}$ & $\begin{array}{l}59 \\
(26.46)\end{array}$ \\
\hline $\begin{array}{l}\text { 7. There should be a unit in universities } \\
\text { dealing with the copyright of educational } \\
\text { materials. }\end{array}$ & $10(4.48)$ & $19(8.52)$ & $\begin{array}{l}49 \\
(21.97)\end{array}$ & $\begin{array}{l}69 \\
(30.94)\end{array}$ & $\begin{array}{l}76 \\
(34.08)\end{array}$ \\
\hline $\begin{array}{l}\text { 8. I think I can decide on the copyright } \\
\text { properties of the materials on Internet. }\end{array}$ & $22(9.87)$ & $49(21.97)$ & $\begin{array}{l}87 \\
(39.01)\end{array}$ & $\begin{array}{l}46 \\
(20.63)\end{array}$ & $\begin{array}{l}19 \\
(8.52)\end{array}$ \\
\hline $\begin{array}{l}\text { 9. I think there is no copyright problems } \\
\text { with using rented CDs and DVDs in class. }\end{array}$ & $\begin{array}{l}54 \\
(24.22)\end{array}$ & $43(19.28)$ & $\begin{array}{l}59 \\
(26.46)\end{array}$ & $\begin{array}{l}40 \\
(17.94)\end{array}$ & $\begin{array}{l}27 \\
(12.11)\end{array}$ \\
\hline $\begin{array}{l}\text { 10. I think it is not legal to use programs } \\
\text { recorded from TV and Radios. }\end{array}$ & $\begin{array}{ll}52 \\
(23.32) \\
\end{array}$ & $49(21.97)$ & $\begin{array}{ll}62 \\
(27.80)\end{array}$ & $\begin{array}{l}39 \\
(17.49)\end{array}$ & $\begin{array}{l}21 \\
(9.42)\end{array}$ \\
\hline $\begin{array}{l}\text { 11. I think it is not legal to use non } \\
\text { licensed software on the computers at } \\
\text { the university campuses. }\end{array}$ & $\begin{array}{l}39 \\
(17.49)\end{array}$ & $46(20.63)$ & $\begin{array}{l}57 \\
(25.56)\end{array}$ & $\begin{array}{l}39 \\
(17.49)\end{array}$ & $\begin{array}{l}42 \\
(18.83)\end{array}$ \\
\hline \multicolumn{6}{|c|}{ Attitudes towards and intentions in using copyrighted materials (AICM) } \\
\hline $\begin{array}{l}\text { 12. An instructional material should not } \\
\text { be used when there is an ambiguity of } \\
\text { copyright. }\end{array}$ & $\begin{array}{l}26 \\
(11.66)\end{array}$ & $44(19.73)$ & $\begin{array}{l}99 \\
(44.39)\end{array}$ & $\begin{array}{l}32 \\
(14.35)\end{array}$ & $\begin{array}{l}22 \\
(9.87)\end{array}$ \\
\hline $\begin{array}{l}\text { 13. I do not want to pay for getting access } \\
\text { to educational materials on Internet. }\end{array}$ & $16(7.17)$ & $19(8.52)$ & $\begin{array}{l}34 \\
(15.25)\end{array}$ & $\begin{array}{l}38 \\
(17.04)\end{array}$ & $\begin{array}{l}116 \\
(52.02)\end{array}$ \\
\hline
\end{tabular}




\begin{tabular}{|c|c|c|c|c|c|}
\hline $\begin{array}{l}\text { 14. I feel disturbed when others copy and } \\
\text { download my educational content } \\
\text { without permission. }\end{array}$ & $\begin{array}{l}52 \\
(23.32)\end{array}$ & 37 (16.59) & $\begin{array}{l}55 \\
(24.66)\end{array}$ & $\begin{array}{l}38 \\
(17.04)\end{array}$ & $\begin{array}{l}41 \\
(18.39)\end{array}$ \\
\hline $\begin{array}{l}\text { 15. I feel worried to infringe copyright } \\
\text { while developing computer supported } \\
\text { instructional materials. }\end{array}$ & $\begin{array}{l}24 \\
(10.76)\end{array}$ & $45(20.18)$ & $\begin{array}{l}83 \\
(37.22)\end{array}$ & $\begin{array}{l}46 \\
(20.63)\end{array}$ & $\begin{array}{l}25 \\
(11.21)\end{array}$ \\
\hline \multicolumn{6}{|c|}{ Perceptions of copyright issues in education (PCE) } \\
\hline $\begin{array}{l}\text { 16. The name of the copyright holder or } \\
\text { creator of an educational material should } \\
\text { be preserved while using it in education }\end{array}$ & $7(3.14)$ & $13(5.83)$ & $\begin{array}{l}33 \\
(14.80)\end{array}$ & $\begin{array}{l}65 \\
(29.15)\end{array}$ & $\begin{array}{l}105 \\
(47.09)\end{array}$ \\
\hline $\begin{array}{l}\text { 17. Copying or distributing of educational } \\
\text { materials should not be regarded as } \\
\text { copyright infringement. }\end{array}$ & $19(8.52)$ & $27(12.11)$ & $\begin{array}{l}58 \\
(26.00)\end{array}$ & $\begin{array}{l}42 \\
(18.83)\end{array}$ & $\begin{array}{l}77 \\
(34.53)\end{array}$ \\
\hline $\begin{array}{l}\text { 18. I agree that downloading educational } \\
\text { materials for teaching is copyright } \\
\text { infringement. }\end{array}$ & $\begin{array}{l}66 \\
(29.60)\end{array}$ & $56(25.11)$ & $\begin{array}{l}57 \\
(25.56)\end{array}$ & $\begin{array}{l}27 \\
(12.11)\end{array}$ & $\begin{array}{l}17 \\
(7.62)\end{array}$ \\
\hline $\begin{array}{l}\text { 19. Putting a material on Internet means } \\
\text { it is for public use and there is no } \\
\text { copyright boundaries. }\end{array}$ & $10(4.48)$ & $17(7.62)$ & $\begin{array}{l}31 \\
(13.90)\end{array}$ & $\begin{array}{l}42 \\
(18.83)\end{array}$ & $\begin{array}{l}123 \\
(55.16)\end{array}$ \\
\hline $\begin{array}{l}\text { 20. Electronic materials used in } \\
\text { educational settings should be considered } \\
\text { within copyright regulations. }\end{array}$ & $\begin{array}{l}31 \\
(13.90)\end{array}$ & $54(24.22)$ & $\begin{array}{l}85 \\
(38.12)\end{array}$ & $\begin{array}{l}39 \\
(17.49)\end{array}$ & $\begin{array}{l}14 \\
(6.28)\end{array}$ \\
\hline $\begin{array}{l}21 . \text { I should use any materials on Internet } \\
\text { in my learning without asking for } \\
\text { copyright permission. }\end{array}$ & $14(6.28)$ & $18(8.07)$ & $\begin{array}{l}60 \\
(26.91)\end{array}$ & $\begin{array}{l}58 \\
(26.00)\end{array}$ & $\begin{array}{l}73 \\
(32.74)\end{array}$ \\
\hline
\end{tabular}

\section{RQ4: What Are The University Students' Opinions About Copyright Issues in Education?}

In order to better interpret the collected qualitative data and to allow the students to express their opinions with their own words, semi-structured interviews were conducted with 20 students on voluntary basis. Findings obtained from the interviews are presented in Table 4. 
Table 4: Comments of students about copyrighted materials

\begin{tabular}{|c|c|c|c|}
\hline \multirow{3}{*}{$\begin{array}{l}\text { Questions } \\
\text { Do you have any information } \\
\text { about copyright laws? Why? }\end{array}$} & \multicolumn{2}{|c|}{ Comments } & \multirow{2}{*}{$\begin{array}{l}\text { Responses } \\
1\end{array}$} \\
\hline & Yes & As it is necessary & \\
\hline & & As I am interested in & 1 \\
\hline & \multirow[t]{2}{*}{ No } & As I do not care & 3 \\
\hline & & As I need to know & 1 \\
\hline & \multirow{3}{*}{$\begin{array}{l}\text { Not } \\
\text { enough }\end{array}$} & As I do not pay attention & 9 \\
\hline & & $\begin{array}{l}\text { As I haven't experienced any } \\
\text { problems }\end{array}$ & 3 \\
\hline & & As I don't care & 2 \\
\hline \multirow[t]{3}{*}{$\begin{array}{l}\text { Do you respect the copyright } \\
\text { of a material? Why? }\end{array}$} & Yes & $\begin{array}{l}\text { As it is necessary to pay } \\
\text { attention }\end{array}$ & 4 \\
\hline & \multirow[t]{2}{*}{ No } & As I don't have any problems & 14 \\
\hline & & As I use it by modifying & 2 \\
\hline $\begin{array}{l}\text { What are your suggestions to } \\
\text { prevent } \quad \text { copyright }\end{array}$ & \multicolumn{2}{|c|}{$\begin{array}{l}\text { There shouldn't be copyright for } \\
\text { educational materials }\end{array}$} & 10 \\
\hline \multirow[t]{6}{*}{ infringements in education? } & \multicolumn{2}{|c|}{ Education should be given } & 5 \\
\hline & \multicolumn{2}{|c|}{ More legal precautions should be taken } & 4 \\
\hline & \multicolumn{2}{|c|}{$\begin{array}{l}\text { Course instructors should pay more } \\
\text { attention }\end{array}$} & 4 \\
\hline & \multicolumn{2}{|c|}{ Costs of materials should be reduced } & 4 \\
\hline & \multicolumn{2}{|c|}{ Religious education should be given } & 2 \\
\hline & \multicolumn{2}{|c|}{ Copyright laws should be abolished } & 1 \\
\hline
\end{tabular}

The findings obtained from the interview data show that the students do not care about the violation of particularly educational materials and do not consider it to be a problem (see Table 4). As the students are not subject to any sanctions when they use a copyrighted material, they do not care about the violation of copyrights. During the interviews, only few students stated that they pay attention to copyrights and everybody should do so. Some other students stated that they care about copyrights and thus, they do not use a material as it is but by modifying it. When a material is used again with small modifications, it is again considered to be copyright infringement. The students think that the most effective way of preventing copyright infringements is the abolishment of copyrights for educational materials. Some other suggestions are giving education about copyright issues and increasing the number of legal precautions. The students stated that some materials are sold in Internet at high prices and this motivates students to violate copyrights. Some of the students also stated that as some of their instructors care about copyrights, they also feel obliged to pay attention to them. Thus, it can be argued that instructors' attitudes are an important factor affecting students' perception of copyrights.

\section{Discussion}

In the present study, it was concluded that though the students actively use Internet for educational purposes, they do not much care about copyrights. Students may prefer to use the materials they want without considering copyrights. In Turkey, copyright regulations were set based on WIPO standards (Çelik \& Akcayir, 2012). However as stated by Jenkins 
(2006) students have created their own ethical norms. A similar finding is reported by Huang (2010), twenty five students out of 33 stated that they violated copyright laws. This is partially because of the frequent use of Internet by the students as stated by Leung and Lee (2012), there is a positive correlation between the time spent on Internet and wrong use of Internet.

The high ratio of students violating copyrights in the present study indicates that students can frequently encounter copyright infringements in their friend circles. Violation of copyrights by their friends is shown as another reason for students' copyright infringements (Huang, 2010). Students witnessing that their friends violate copyrights and do not encounter any punishment may feel motivated to use ready materials instead of wasting their time researching. They may have the idea that nothing would change if they violated copyrights as their friends do not encounter any sanctions as a result of copyright infringement (Sisti, 2007). This can be assumed to be an example of Bandura's (1986) moral disengagement in his social learning theory and majority impact and peer pressure (Gibson, 2000).

Students also mentioned the necessity of religious education for the prevention of copyright infringements. This finding is parallel to what is reported by (Koul, 2012). Students having strong religious beliefs exhibit lower tendency towards academic dishonesty and even if they exhibit such behavior, they honestly confess it. Religious education attaches greater importance to moral values and personal rights.

During the interviews, though students did not state that they experience any problems related to time, in literature, it is reported that students of digital era have to do a lot of works in a short time; thus, they feel obliged to violate copyrights (Blum, 2011). Formerly, information was sought in libraries within books; hence, it was not easy to copy the information as it is today.

The findings of the current study show that the students think that there should not be copyrights for educational materials. However, it is not correct to use any materials presented in Internet environment by considering them educational materials. Materials obtained illegally also give some harm to the economy of the country. As the producers cannot sell as they plan, they may have some financial problems (DeFosse, 2012). Though it is time-consuming, developing one's own materials may prevent copyright infringements (Heffernan \& Wang, 2008). Moreover, when students develop their own materials, they will be more respectful to others' works. Another reason for students to want educational materials to be free is the high cost of these materials. During the interviews, students stated that they cannot afford to buy high-cost materials. According to Kuzu (2009), highcost materials may direct people to the violation of copyrights. However, according to Huang (2010), though decreasing the prices might constitute a short-term solution, in a long-term, this will have adverse effects. Instead of decreasing the costs, making wholesale purchases by educational institutions and offering students some benefits of these wholesale purchases may constitute a long-term solution. When the steps taken in copyright issues about educational materials in Turkey are examined, it is seen that within the context of a project conducted by Turkish Academy of Sciences in 2007, a protocol was signed with totally 45 universities to generate open course materials data base in Turkey (TUBA, 2014). It is free to have access to and use the course materials offered in this data 
base. The data base provides some flexibility in terms of copyrights and offers materials to be used by everyone wanting to improve themselves; thus, it has become an important source of life-long learning (TUBA, 2014).

The reasons laying the ground for the violation of copyrights are also related to educators and politicians when there is no legal sanction, students do not encounter with any problems and thus they are encouraged to violate copyrights. Educators need to pay great attention to copyright issues. According to Lau and Yuen (2014), educators should take responsibility and encourage students to comply with copyright laws. Educators should be good models for their students (Herrington, 2010). Students may say that if we had had to pay attention to copyrights, the teacher should have told this (Sisti, 2007). Students may think that the educator does not care about copyright issues. This contention is supported by the interview findings of the present study. The students stated that when the educator is careful about violation of copyrights, they also pay attention to copyright issues. Thus, instructors need to be knowledgeable about copyright laws (McGrail \& McGrail, 2009). By using some programs such as iThenticate, Turnitin.com, instructors can control whether their students are violating copyright laws. These software programs also offer some additional features such as giving feedback to students, requiring colleagues' evaluations and scoring. Such software programs are also time-saving for instructors. However, when such programs are used by instructors, the relationship between students and the instructors is negatively affected and this may have some adverse effects on teachinglearning process (Herrington, 2010). Moreover, instructors should focus on students' learning process rather than score (McCabe et al., 1999). Students need to be encouraged to adopt an educational perception requiring inquiry and discovery rather than the exploitation of already generated information.

During the interviews, the students suggested that ethical education should be given. In a similar manner, Ben-Jacob (2005) conducted a study and at the end of this study, ethics course was incorporated into the curriculum and some positive outcomes were obtained. Moreover, universities can develop and enforce own copyright policies (Loggie et al., 2006). These developed school policies should be announced in their websites and hung on different parts of the university as posters. Developing policies and announcing them through different means may alleviate students' confusion about the issue.

\section{Conclusion}

The purpose of the current study is to investigate the current state, attitudes and suggestions of the university students in relation to the issue of copyright violation that bothers educational circles and is overlooked from time to time. The current study clearly reveals that the issue of copyright violation is still a serious problem. Students have created their own ethical norms and do not take much care about copyrights. There are some factors motivating students to violate copyrights such as high prices, inadequate information and indifference. In addition to this, some students hold the belief that educational materials are not under the protection of copyright laws. Yet, putting all the responsibility on students' shoulders to solve the problem of copyright violation won't solve the problem. The findings obtained from the interviews conducted with the students show that both instructors and the university management should take active role in the solution of this problem. As long as the instructors take the required care for the violation of 
copyrights, students will be sensitive to this issue. The instructors should be good models for students. University management should take some precautions to discourage students from violating copyrights so that students should know that they will be confronted with some sanctions when they violate copyrights. Otherwise, great disservice would be made to copyright owners and science.

It should be noted that in the present study, the participants' level of internet use for educational purposes is quite high. Different results might be obtained for a group with lower level of internet use. For instance, for a group less using internet for educational purposes, different perception of copyrights can be found.

In conclusion, the problem can be solved through the integrated efforts of students, instructors and managements. Thus, internet can be used more fairly in educational environments.

\section{Suggestions}

The following existing gaps and needs in copyright issues in education were derived from the findings of this study.

- Instructors and the university management should take some precautions such as;

○ using some plagiarism checker software (e.g. iThenticate, Turnitin.com),

- making students aware of copyright issues,

○ being good models for their students,

o stating that violating copyrights is unacceptable.

- Content creators, publishers and distributors of multimedia data should use copyright protection techniques such as digital watermarking.

- Educational institutions need to provide adequate copyright law training for their instructors and students.

Future research;

- should focus on instructors, book writers, university managements and other stakeholders perspectives and should investigate their opinions and solutions about copyright issues in education,

- should examine effects of precautions by conducting empirical studies,

- should be conducted in different countries to identify results of different cultures and copyright laws,

- should focus on other related topics such as academic dishonesty and ethical issues, 
- should investigate factors that may have a positive impact on the copyright infringements.

\section{References}

Akbulut, Y., Uysal, Ö., Odabasi, H. F., \& Kuzu, A. (2008). Influence of gender, program of study and PC experience on unethical computer using behaviors of Turkish undergraduate students. Computers \& Education, 51(2), 485-492.

Arnold, M., Schmucker, M., \& Wolthusen, S. D. (2002). Techniques and applications of digital watermarking and content protection: Artech House.

Austin, M. J., \& Brown, L. D. (1999). Internet plagiarism: Developing strategies to curb student academic dishonesty. The Internet and higher education, 2(1), 21-33.

Bandura, A. (1986). Social foundations of thought and action: Englewood Cliffs, NJ Prentice Hall.

Ben-Jacob, M. G. (2005). Integrating computer ethics across the curriculum: A case study. Educational Technology \& Society, 8(4), 198-204.

Beycioglu, K. (2009). A cyberphilosophical issue in education: Unethical computer using behavior-The case of prospective teachers. Computers \& Education, 53(2), 201-208.

Blum, S. D. (2011). My word!: Plagiarism and college culture: Cornell University Press.

Copyright (2014). The digital millennium copyright act of 1998. Retrieved June 8, 2014, from http://www.copyright.gov/legislation/dmca.pdf

Çelik, S., \& Akcayir, M. (2012). Perceptions of Academic Staff toward Copyright of Educational Materials. World Journal on Educational Technology, 4(2), 68-80.

DeFosse, E. B. (2012). Ask not what E-books do for People, but what people do with E-books: An exploration of the uses and gratifications theory in regards to E-book technology. (Unpublished master's thesis), USA.

Elo, S., \& Kyngäs, H. (2008). The qualitative content analysis process. Journal of advanced nursing, 62(1), 107-115.

Frohmann, B. (2008). Subjectivity and information ethics. Journal of the American Society for Information Science and Technology, 59(2), 267-277.

Gibson, K. (2000). Excuses, excuses: Moral slippage in the workplace. Business Horizons, 43(6), 65-72.

Heffernan, N., \& Wang, S. (2008). Copyright and multimedia classroom material: a study from Japan. Computer Assisted Language Learning, 21(2), 167-180.

Herrington, T. A. K. (2010). Intellectual Property on Campus: Students' Rights and Responsibilities: Southern Illinois University Press.

Huang, J. P. (2010). The Ethical Lives of College Students in the Digital Age. (3436591 Ph.D.), The Claremont Graduate University, Ann Arbor. Retrieved from http://search.proquest.com/docview/817401448? accountid=16369 ProQuest Dissertations \& Theses Global database.

Jenkins, H. (2006). Confronting the Challenges of Participatory Culture: Media Education for the 21st Century. An Occasional Paper on Digital Media and Learning. John D. and Catherine T. MacArthur Foundation.

Karim, N. S. A., Zamzuri, N. H. A., \& Nor, Y. M. (2009). Exploring the relationship between Internet ethics in university students and the big five model of personality. Computers \& Education, 53(1), 86-93. 
Kim, J. E., \& Kim, J. (2012). Determinants of online problematic behavior among teen users: Data from South Korea. Retrieved April 11, 2014, from http://www.consumerinterests.org

Koul, R. (2012). Multiple motivational goals, values, and willingness to cheat. International Journal of Educational Research, 56, 1-9.

Kuzu, A. (2009). Problems related to computer ethics: Origins of the problems and suggested solutions. The Turkish Online Journal of Educational Technology, 8(2), 91110.

Lan, J., \& Dagley, D. (1999). Teaching via the Internet: A Brief Review of Copyright Law and Legal Issues. AACE Journal, 1(11), 25-30.

Lau, W. W., \& Yuen, A. H. (2014). Internet ethics of adolescents: Understanding demographic differences. Computers \& Education, 72, 378-385.

Lenhart, A., \& Madden, M. K. (2005). Teen content creators and consumers: More than half of online teens have created content for the Internet; and most teen downloaders think that getting free music files is easy to do: Pew Internet \& American Life Project.

Leung, L., \& Lee, P. S. (2012). Impact of internet literacy, internet addiction symptoms, and internet activities on academic performance. Social Science Computer Review, 30(4), 403-418.

Liang, Z., \& Yan, Z. (2005). Software piracy among college students: A comprehensive review of contributing factors, underlying processes, and tackling strategies. Journal of Educational Computing Research, 33(2), 115-140.

Lin, H. (2007). The ethics of instructional technology: issues and coping strategies experienced by professional technologists in design and training situations in higher education. Educational technology research and development, 55(5), 411-437.

Loggie, K. A., Barron, A. E., Gulitz, E., Hohlfeld, T. N., Kromrey, J. D., Venable, M., \& Sweeney, P. (2006). An analysis of copyright policies for distance learning materials at major research universities. Journal of Interactive Online Learning, 5(3), 224-241.

Love, P. G., \& Simmons, J. (1998). Factors influencing cheating and plagiarism among graduate students in a college of education. College Student Journal, 32(4), 539-550.

Mabry, C. K., \& O'Driscoll, T. (2003). Lessons from adult education: Identifying and exploring emerging ethical issues in technologically enhanced performance. Performance Improvement Quarterly, 16(4), 78-93.

McCabe, D. L. (1997). Classroom cheating among natural science and engineering majors. Science and Engineering Ethics, 3(4), 433-445.

McCabe, D. L., Trevino, L. K., \& Butterfield, K. D. (1999). Academic integrity in honor code and non-honor code environments: A qualitative investigation. Journal of Higher Education, 70, 211-234.

McGrail, J. P., \& McGrail, E. (2009). What's wrong with copyright: Educator strategies for dealing with analog copyright law in a digital world. Innovate: Journal of Online Education, 5(3), 1-6.

Mir, N. (2014). Copyright for web content using invisible text watermarking. Computers in Human Behavior, 30, 648-653.

Moon, J. (1999). How to...stop students from cheating. Retrieved April 10, 2014, from http://www.timeshighereducation.co.uk/news/how-tostop-students-fromcheating/147580.article

OCWC (2014). OCWC global at a glance. Retrieved June 8, 2014, from http://www.oeconsortium.org 
Renard, L. (1999). Cut and paste 101: Plagiarism and the net. Educational Leadership, 57(4), 38-42.

Ross, K. A. (2005). Academic dishonesty and the Internet. Communications of the ACM, 48(10), 29-31.

Siponen, M. T., \& Vartiainen, T. (2005). Attitudes to and factors affecting unauthorized copying of computer software in Finland. Behaviour \& Information Technology, 24(4), 249-257.

Sisti, D. A. (2007). How do high school students justify internet plagiarism? Ethics \& Behavior, 17(3), 215-231.

Storch, E., \& Storch, J. (2002). Fraternities, sororities, and academic dishonesty. College Student Journal, 36(2), 247-252.

Sukrung, K. (2003). Making the grade. Retrieved April 11, 2014, from http://www.bangkokpost.com/education/site2003/ftmy2703.htm

Szabo, A., \& Underwood, J. (2004). Cybercheats is information and communication technology fuelling academic dishonesty? Active Learning in Higher Education, 5(2), 180-199.

Tang, G. H. (2010). Is administrative enforcement the answer? Copyright protection in the digital era. Computer Law \& Security Review, 26(4), 406-417. doi: http://dx.doi.org/10.1016/j.clsr.2010.05.006

The Josephson Institute (2006). The ethics of American youth: 2006. Retrieved May 1, 2014, from http://charactercounts.org/programs/reportcard/2006/index.html

Trautmann, S. T., van de Kuilen, G., \& Zeckhauser, R. J. (2013). Social Class and (Un) Ethical Behavior A Framework, With Evidence From a Large Population Sample. Perspectives on Psychological Science, 8(5), 487-497.

TUBA (2014). Türkiye bilimler akademisi. Retrieved April 10, 2014, from http://www.tuba.gov.tr

Twigg, C. A. (2000). Who owns online courses and course materials? Intellectual property policies for a new learning environment. Retrieved May 1, 2014, from http://www.center.rpi.edu/PewSym/mono2.html

Underwood, J. D. (2003). Student attitudes towards socially acceptable and unacceptable group working practices. British Journal of Psychology, 94(3), 319-337.

Whitley, H. P., \& Starr, J. (2010). Academic dishonesty among pharmacy students: does portable technology play a role? Currents in Pharmacy Teaching and Learning, 2(2), 94-99.

Underwood, J., \& Szabo, A. (2003). Academic offences and e-learning: Individual propensities in cheating. British Journal of Educational Technology, 34(4), 467-477. 